\title{
Asymmetric gene flow and the evolutionary maintenance of genetic diversity in small, peripheral Atlantic salmon populations
}

\author{
Sofía Consuegra ${ }^{1,4, *}$, Eric Verspoor ${ }^{2}$, David Knox $^{2} \&$ Carlos García de Leániz ${ }^{3}$ \\ ${ }^{1}$ Institute of Zoology, Zoological Society of London, NWI 4RY London, UK; ${ }^{2}$ Freshwater Laboratory, \\ Fisheries Research Service, Pitlochry, Perthshire, Scotland PH16 5LB, UK; ${ }^{3}$ School of Biological \\ Sciences, University of Wales Swansea, Swansea SA2 8PP, UK; ${ }^{4}$ Gatty Marine Laboratory, University of \\ St. Andrews, St. Andrews, Fife, Scotland, KY16 8LB, UK (*Corresponding author: Phone: +44-1334-463- \\ 449; Fax: +44-1334-463-443; E-mail: sonia.consuegra@st-andrews.ac.uk)
}

Received 16 November 2004; accepted 21 December 2004

Key words: allelic richness, asymmetric gene flow, Atlantic salmon, bottlenecks, effective population size, heterozygosity, microsatellites

\begin{abstract}
Small populations may be expected to harbour less genetic variation than large populations, but the relation between census size $(N)$, effective population size $\left(N_{\mathrm{e}}\right)$, and genetic diversity is not well understood. We compared microsatellite variation in four small peripheral Atlantic salmon populations from the Iberian peninsula and three larger populations from Scotland to test whether genetic diversity was related to population size. We also examined the historical decline of one Iberian population over a 50 -year period using archival scales in order to test whether a marked reduction in abundance was accompanied by a decrease in genetic diversity. Estimates of effective population size $\left(N_{\mathrm{e}}\right)$ calculated by three temporal methods were consistently low in Iberian populations, ranging from 12 to 31 individuals per generation considering migration, and from 38 to 175 individuals per generation if they were regarded as closed populations. Corresponding $N_{\mathrm{e}} / N$ ratios varied from 0.02 to 0.04 assuming migration (mean $=0.03$ ) and from 0.04 to 0.18 (mean $=0.10$ ) assuming closed populations. Population bottlenecks, inferred from the excess of heterozygosity in relation to allelic diversity, were detected in all four Iberian populations, particularly in those year classes derived from a smaller number of returning adults. However, despite their small size and declining status, Iberian populations continue to display relatively high levels of heterozygosity and allelic richness, similar to those found in larger Scottish populations. Furthermore, in the R. Asón no evidence was found for a historical loss of genetic diversity despite a marked decline in abundance during the last five decades. Thus, our results point to two familiar paradigms in salmonid conservation: (1) endangered populations can maintain relatively high levels of genetic variation despite their small size, and (2) marked population declines may not necessarily result in a significant loss of genetic diversity. Although there are several explanations for such results, microsatellite data and physical tagging suggest that high levels of dispersal and asymmetric gene flow have probably helped to maintain genetic diversity in these peripheral populations, and thus to avoid the negative consequences of inbreeding.
\end{abstract}




\section{Introduction}

Preventing the loss of genetic diversity is a priority in conservation programmes (Avise 1994; Frankham et al. 2002). Small populations are more prone to inbreeding and genetic drift, and consequently are more likely to lose rare alleles and show a reduction in heterozygosity (Daniels et al. 2000; Sherwin and Moritz 2000). Fluctuations in population size may also cause the loss of neutral and non-neutral alleles, which might be potentially important for the future of the species (Vucetich and Waite 1999). In general, loss of genetic diversity might be expected to impair fitness (Vrijenhoek 1994; Keller et al. 1994) and can ultimately result in the extinction of populations (Saccheri et al. 1998; Keller and Waller 2002).

A critical parameter for the management and conservation of natural populations (Allendorf et al. 1997) is the effective population size $\left(N_{\mathrm{e}}\right)$, as it determines the rate at which genetic diversity is lost in the population by genetic drift (Franklin 1980). In most populations, one effective migrant per generation is in principle enough to avoid the adverse effects of genetic drift, although more migrants may be needed to offset drift when the ratio $N_{\mathrm{e}} / N$ (effective population size/census size) is very low and genetic drift is more pronounced (Mills and Allendorf 1996; Wang 2004). Effective population size is usually much lower than the census size $(N)$ and the estimates are particularly sensitive to fluctuations in abundance (Frankham 1996; Vucetich et al. 1997; Hauser et al. 2002), resulting in $N_{\mathrm{e}} / N$ values lower than the 0.5 ratio predicted theoretically (Nunney 1993).

Estimating $N_{\mathrm{e}}$ from census data is often difficult, especially in species with complex life cycles and varying habitat preferences where multiple censuses may be necessary to obtain reliable estimates (Vucetich and Waite 1998). Fortunately, changes in allelic frequencies over time can also be used to estimate $N_{\mathrm{e}}$ (Waples 1998; Wang and Whitlock 2003) and have proved particularly useful in cases where census estimates are difficult to obtain, such is often the case with fish populations (Hedrick et al. 1995). On the other hand, $N_{\mathrm{e}}$ estimates based on temporal fluctuations in allelic frequencies may yield inaccurate results in species with overlapping generations (Waples 2002a), especially if the number of generations between samples is small (Jorde and Ryman 1995).

The decline of numerous salmon populations across the distribution area (Parrish et al. 1998; WWF 2001) has prompted the development of conservation programs (Dodson et al. 1998), though the best strategy for preserving local adaptations while preventing the loss of genetic diversity remains controversial (Adkison 1995). Thus, while homing behaviour can make salmon populations reproductively isolated and locally adapted (Taylor 1991), it can also make them particularly vulnerable to the loss of rare alleles through drift, especially in the case of small populations (Storfer 1999; Moran 2002). Isolation can also make small populations more vulnerable to genetic and demographic fluctuations and more prone to extinction (Primack 1998). On the other hand, overlapping generations and the presence of mature male parr (MMP) that participate in reproduction at an early age (Jones and Hutchings 2001; Taggart et al. 2001) can increase $N_{\mathrm{e}}$, particularly in southern latitudes (Martinez et al. 2000) where early maturation is common due to elevated temperatures.

The present European distribution of the Atlantic salmon (Salmo salar) is thought to reflect postglacial recolonisation from multiple refugia after the Last Glacial Maximum (Bernatchez and Wilson 1998; Consuegra et al. 2002). At the southern limit, populations from the Iberian glacial refugium have declined dramatically over the last 100 years, particularly during the last decades (García de Leániz and Martínez 1988; Garcia de Leániz et al. 2001), and their effective size may be under the limits suggested to preserve variability over time (Franklin 1980; Lande 1995). Yet, no estimates of $N_{\mathrm{e}}$ are currently available for these populations, making it difficult to develop conservation guidelines based on census estimates alone.

To examine these issues, we compared microsatellite variation in four small Atlantic salmon populations from the Iberian peninsula and three larger populations from Scotland. We also examined the historical decline of one Iberian population over a 50-year period using archival scales, and obtained estimates of the relation between census size, effective population size and genetic diversity in order to test (a) whether Iberian salmon populations display reduced genetic diversity 
in relation to other European populations, as their low abundance and endangered status might suggest, and (b) whether a historical population bottleneck in one of the populations was accompanied by a corresponding decrease in genetic diversity, as theory might predict.

\section{Materials and methods}

\section{Study populations and collection of samples}

Adipose fins and scale samples were collected from 700 wild angled Atlantic salmon and spawners (sampled without replacement) entering the rivers Asón ( $\mathrm{n}=121$, annual samples sizes 21-29), Pas $(\mathrm{n}=200$, annual samples sizes 25-101), Nansa $(\mathrm{n}=249$, annual samples sizes 26-66), and Deva $(\mathrm{n}=130$, annual samples sizes 6-49) during 19962000. These are short Iberian rivers, located near the southernmost limit of the species' endemic distribution (Figure 1) and represent extreme, marginal habitats for Atlantic salmon, being prone to severe droughts and high water temperatures in summer (Garcia de Leániz et al. 2001). Tissue samples $(\mathrm{n}=50$ each $)$ were also obtained from adults returning in 1998 to three Scottish rivers (North Esk, Shin and Oykel) to provide comparative data from larger, more stable populations (Shearer 1992).

The four Iberian salmon populations had been stocked with foreign ova intermittently from 1980 to 1991, though few foreign fish - if any - seem to have returned to reproduce as adults (Garcia de Leániz et al. 1989; Verspoor and Garcia de Leániz 1997). More recently, a supplementation programme based on the stocking of native juveniles into the rivers of origin was initiated in 1996 (Garcia de Leániz et al. 2001). However, this is unlikely to have affected our results since hatchery-reared adults (all identified by fin-clipping) were excluded from analysis, return rates were low $(0.1-0.3 \%)$, and the first offspring would not have returned until 2000, our last sampling year. In any event, the four study populations appear to remain genetically distinct (Consuegra et al. 2002).

To examine historical trends in population size and in genetic diversity, archived scales were obtained from 95 adult salmon angled in the river Asón from 1948 to 1989. Since the number of historical samples was limited and the number of samples per year was not uniform, they were pooled by decade in order to increase the sample size; a comparative analysis was then carried out across decades, with the exception of the 1970 decade from which no scales were available.

\section{Census size estimates}

The four Iberian populations are small (average catch $=34-71$ adults/river during 1996-2000) and have been exploited exclusively by rod and line over the same fishing season since 1949 (García de Leániz and Martinez 1988; García de Leániz et al. 1989). Since fishing effort has continued to increase (García de Leániz et al. 2001), the recent decline in angling catches is probably indicative of a general decrease in salmon abundance, particularly in the R. Asón (Figure 2).

For each river, individuals were assigned to their year classes (cohorts) by scale reading, and year class strength $(S)$ was estimated as the total (cumulative) number of angled adults derived from each cohort, assuming that the most abundant cohorts would tend to yield the largest catches. This is a reasonable assumption for these populations, since catch statistics are complete, multiple spawners are rare $(<1 \%)$, and rod catches appear to be correlated with run sizes (Garcia de Leániz et al. unpublished). We obtained annual census size estimates of the breeding populations, based on redd counts and sex ratio of spawners (Ardren and Kapuscinski 2003), assuming that each redd represented on average one spawning female. Although the construction of more than one redd per female (e.g., Taggart et al. 2001) may introduce an upward bias in the estimates of the number of spawners, this may be partially offset by redd overlapping in the study populations. In the case of the historic data for the R. Asón (before 1981), we used a mean exploitation rate by anglers of 0.40 and a mean sex ratio $(\mathrm{M} / \mathrm{F})$ of 0.842 (means of the period 1979-1996; Garcia de Leániz et al. 1992 and unpublished data) to estimate the number of anadromous breeders directly from rod catches. To account for the contribution of mature male parr, we used an average density of 8 mature male parr per spawning female (Figure 3 ) to derive more realistic estimates of the sizes of the breeding populations in each river. Annual censuses of the total number of spawners $\left(N_{\mathrm{t}}\right)$ were transformed into census sizes per generation $\left(N_{\mathrm{T}}\right)$ in order to 


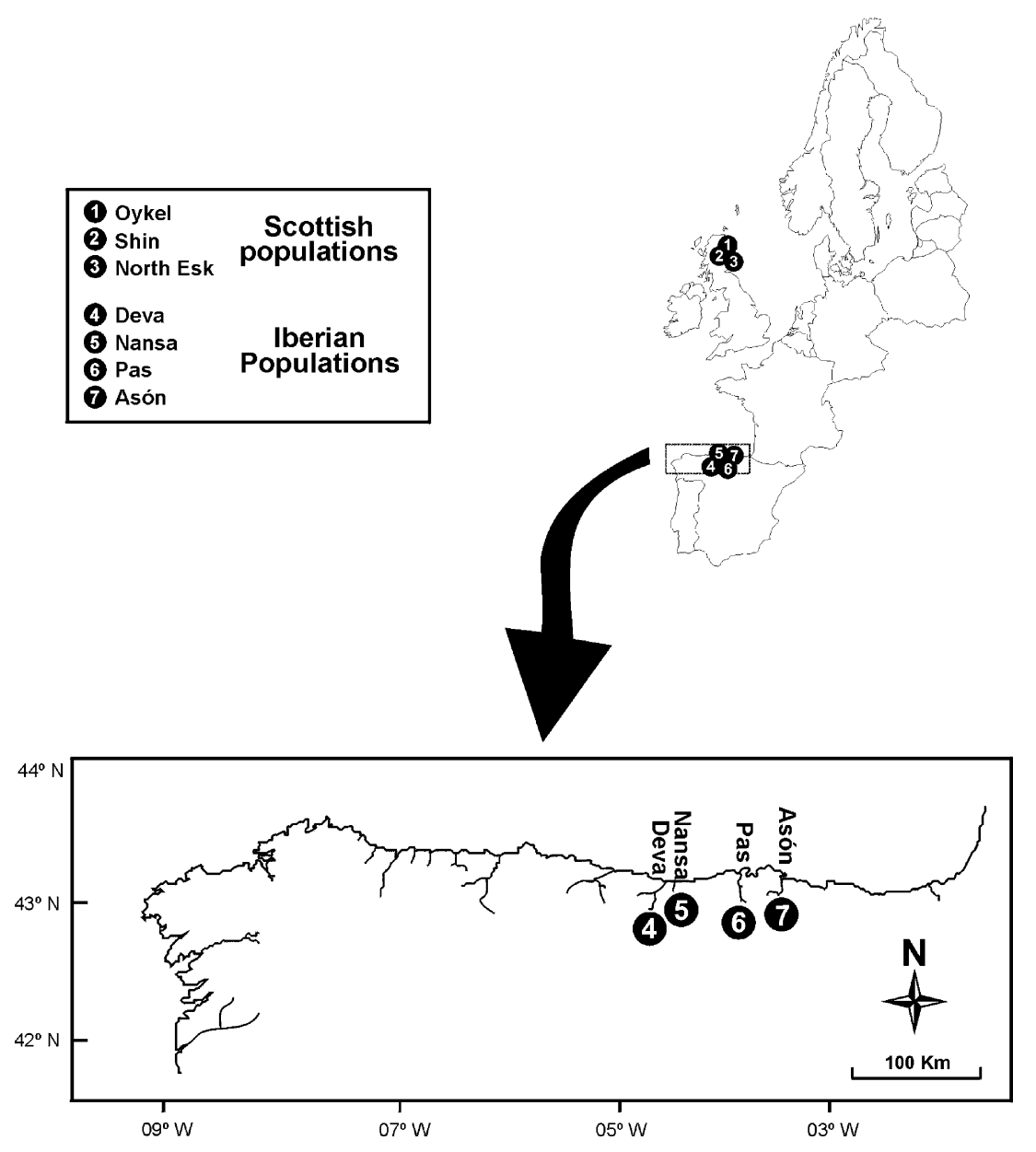

Figure 1. Map showing location of the four small, peripheral Atlantic salmon populations from the Iberian peninsula, and the three relatively large populations from Scotland analysed for microsatellite diversity in the present study.

compute $N_{\mathrm{e}} / N$ ratios per generation, by multiplying the average $N_{\mathrm{t}}$ across years by generation length (Table 1, see below). Although these estimates of census size do not take into account multiple spawners, such bias would be negligible here due to their low frequency in the study populations.

\section{Microsatellite analysis}

Total DNA was extracted from adipose fins according to Taggart et al. (1992) and was then amplified with primers for six (SSsp1605, SSsp2201, SSsp2210, SSsp2213, SSsp2215 and SSsp2216; Iberian populations) or four (SSsp1605, SSsp2201, SSsp2210 and SSsp2216; Scottish populations) tetranucleotide microsatellites (Paterson et al. 2004), known to be variable in other Euro- pean Atlantic salmon populations (Verspoor and Knox unpublished). A 1:8 dilution was made of the extracted DNA, and $0.5 \mu \mathrm{l}$ of this dilution was used for multiplex amplification with fluorescentlabelled primers according to allele size: FAM for SSsp1605, SSsp2201 and SSsp2210, HEX for SSsp2213, and NED for SSsp2215 and SSsp2216. Final amplification volume was $5 \mu \mathrm{l}$ distributed as follows: sterilized distilled water, $0.5 \mu 1$ amplification bufferII $10 \times$ (Perkin-Elmer), $0.5 \mu \mathrm{l}$ dNTPs $2 \mathrm{mM}, 0.5 \mu \mathrm{l} \mathrm{MgCl}_{2} 25 \mathrm{mM}, 0.15$ units of Taq Gold (Perkin-Elmer). Primer concentrations were $0.10 \mu \mathrm{M}$ for SSsp1605, $0.38 \mu \mathrm{M}$ for SSsp2201, $0.07 \mu \mathrm{M}$ for SSsp2210, $0.20 \mu \mathrm{M}$ for SSsp2213, $0.06 \mu \mathrm{M}$ for SSsp2215 and $0.35 \mu \mathrm{M}$ for SSsp2216. In those samples where multiplex did not work for some microsatellites, these were repeated independently. Microsatellites were 

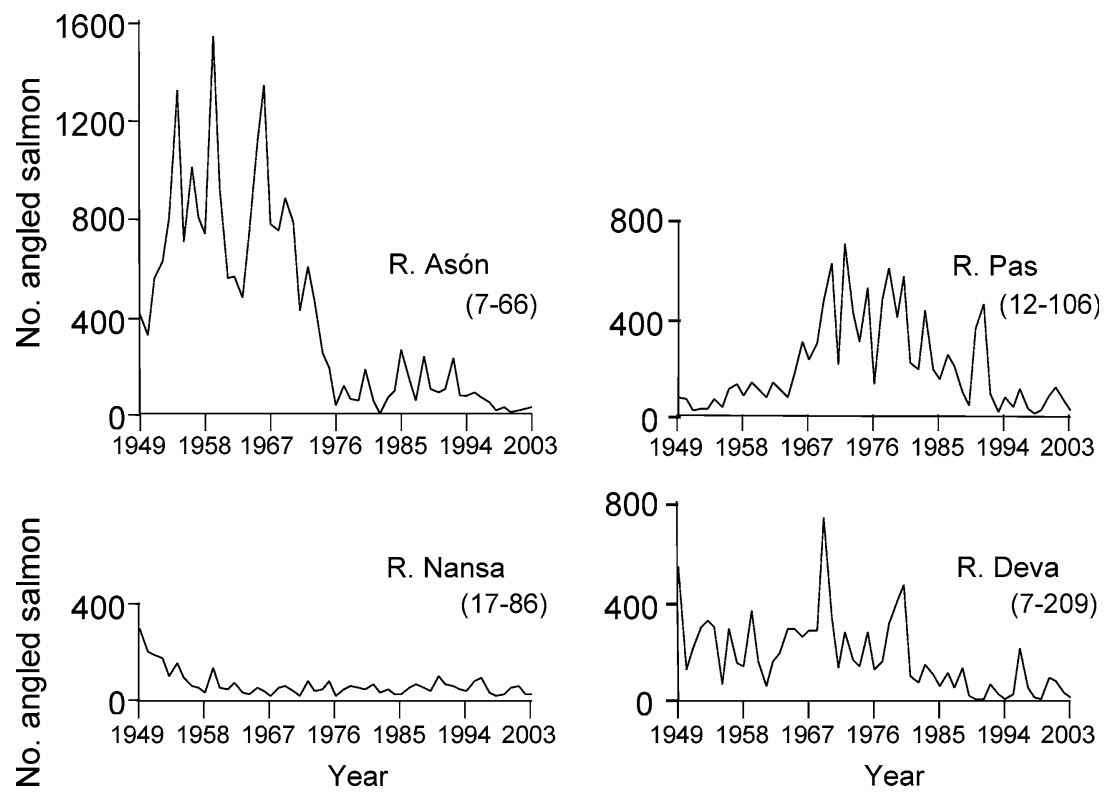

Figure 2. Annual rod and line catch (no. angled adult salmon) in the four Iberian populations since 1949. Range of angling catches during 1996-2000 is shown in parentheses.

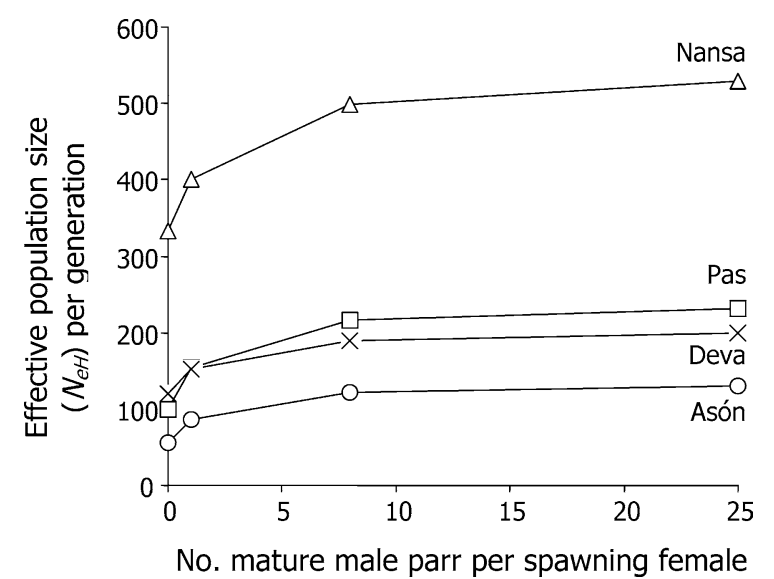

Figure 3. Estimated effect of different number of mature male parr $(0,1,8,25)$ per spawning female on demographic estimates of effective population size per generation in Iberian populations $\left(N_{\mathrm{eH}}\right.$, harmonic means 1996-2000).

analysed on an Applied Biosystems ABI377 DNA sequencer and allele size was estimated with the aid of GeneScan and Genotyper (Applied Biosystems) using the internal marker (TAMRA 500) as a reference standard.

Total DNA from historical scales from the R. Asón was extracted in 5\% Chelex (Beacham and Dempson 1998), $10 \mu \mathrm{l}$ of the extracted DNA was then amplified (hot-start, 40 cycles) for the same microsatellites and genotyping was repeated at least twice. SSsp2216 amplified poorly due to the large size of some of the alleles and was omitted from analysis.

\section{Analysis of genetic variation and evidence of population bottlenecks}

Genetic diversity, as well as observed and expected heterozygosities, were calculated using GENETIX 4.01 (Laboratoire Génome et Populations, CNRS UPR 9060, Montpellier France). Deviations from Hardy-Weinberg equilibrium were tested for each locus using GENEPOP 3.2 (Raymond and Rousset 1995) with 1000 iterations and levels of significance were corrected using the sequential Bonferroni method (Rice 1989). Genetic differentiation between populations was assessed by exact tests (Raymond and Rousset 1995) using GENEPOP 3.2.

A significant heterozygous deficiency was observed for microsatellites SSsp2213 and SSsp2215 in all populations, but not for the other four microsatellites. As this suggested the existence of null alleles (Brookfield 1996; Hedrick 2000), we adopted the corrective procedures described in Brookfield (1996) and Dempster et al. (1977) using GENEPOP 3.2. Corrected frequencies were then 
Table 1. Age distribution, average age at spawning and adjusted generation length (see text) for wild anadromous spawners in Iberian populations, 1996-2000

\begin{tabular}{|c|c|c|c|c|c|c|c|c|}
\hline \multirow[t]{2}{*}{ Population } & \multirow[t]{2}{*}{$N$} & \multicolumn{4}{|c|}{$\begin{array}{l}\text { Age class } \\
\text { distribution }\left(A_{i}, \mathrm{yr}\right)\end{array}$} & \multirow[t]{2}{*}{$\begin{array}{l}\text { Avg. age at spawning } \\
(T, y r)\end{array}$} & \multirow[t]{2}{*}{$\begin{array}{l}\text { Maximum } \\
\text { body size }(\mathrm{kg})\end{array}$} & \multirow[t]{2}{*}{$\begin{array}{l}\text { Adjusted generation } \\
\text { length }\left(T_{\mathrm{adj}}, \mathrm{yr}\right)\end{array}$} \\
\hline & & 2 & 3 & 4 & 5 & & & \\
\hline Asón & 88 & 0.39 & 0.51 & 0.10 & 0.00 & 2.72 & 4.42 & 2.84 \\
\hline Pas & 109 & 0.29 & 0.56 & 0.13 & 0.02 & 2.87 & 4.65 & 3.04 \\
\hline Nansa & 177 & 0.57 & 0.37 & 0.06 & 0.00 & 2.49 & 6.19 & 2.65 \\
\hline Deva & 29 & 0.48 & 0.49 & 0.03 & 0.00 & 2.55 & 3.56 & 2.65 \\
\hline
\end{tabular}

used to estimate the number of individuals homozygous and heterozygous for null alleles in each sample. Deviations from Hardy-Weinberg were examined by an exact Markov test after 1000 iterations.

The pattern of differentiation between present and historical populations was assessed by neighbour-joining dendrograms with 1000 bootstrap replications based on the $D_{\mathrm{A}}$ distance (Nei et al. 1983) using DISPAN (Ota 1993). Total allelic richness and mean allelic richness per population (Mousadik and Petit 1996) were estimated with the CONTRIB program (Petit et al. 1998) approximated to 10 genes as minimum population size to compare with the historical samples, with low amplification success rate for some of the microsatellites. Differences in allelic richness between populations were tested by the Wilcoxon sign test (Sokal and Rohlf 1995) using SYSTAT 9.0.

Evidence for the existence of genetic bottlenecks was analysed with the BOTTLENECK program (Piry et al. 1999), assuming a two-step mutation model (TPM) and the infinite allele mutation (IAM) model and using a Wilcoxon signrank test. Those year classes with reduced sample size were excluded from the analysis (i.e. Asón 1997 and Deva 1995). Allelic heterogeneity between historical and present samples was tested with GENEPOP 2.0 and probabilities were corrected by the Bonferroni method. All samples from 1996 to 2000 were considered for allelic richness and heterozygosity in the modern Asón population, as no significant differences in the allelic frequency distribution was observed between angled fish and spawners for any of the microsatellites. The PERMUTE program (Brookes et al. 1997) was employed to construct individual genotype permutations to test whether there had been a significant reduction in heterozygosity be- tween historical and modern samples of different sample sizes. Changes in heterozygosity were also assessed by paired $t$-tests.

Estimates of effective population size $\left(N_{e}\right)$

$N_{\mathrm{e}}$ was estimated independently by demographic and genetic methods. First, because the presence of relatively large numbers of small-sized mature male parr (MMP) can greatly skew the sex ratio amongst spawners, we modelled the effect of varying the density of MMP (from 0 to $25 \mathrm{MMP} /$ female) on demographic estimates of the effective number of breeders according to the expression of Wright (1938) for uneven sex ratios:

$$
N_{\mathrm{b}}=\frac{4 N_{\mathrm{m}} N_{\mathrm{f}}}{N_{\mathrm{m}}+N_{\mathrm{f}}}
$$

where $N_{\mathrm{m}}$ and $N_{\mathrm{f}}$ are the annual census estimates of the number of male and female spawners respectively, as described previously. An average density of 8 MMP per female spawner was used as a likely upper value to approximate the demographic contribution of mature parr, based on field data from Iberian populations (Martinez et al. 2000) and the simulated relationship between density of mature male parr and the increase in the effective number of breeders due to unequal sex ratio (Figure 3). Next, following Shrimpton and Heath (2003), we used the harmonic mean to estimate the annual effective population size based on annual fluctuations in the total number of breeders, adjusted by the presence of mature male parr, as above $\left(N_{\mathrm{bH}}\right)$. We then multiplied these annual estimates by generation length to obtain effective population size per generation $\left(N_{\mathrm{eHT}}\right)$ that could be compared with genetic estimates of $N_{\mathrm{e}}$ obtained during the same time periods. Although this method assumes strict semelparity, 
it can also be applied with little bias when there is a low incidence of multiple spawners (Waples 1990; Ardren and Kapuscinski 2003), as was the case in our populations (iteroparity $<1 \%$ amongst anadromous spawners).

Genetic estimates of effective population size $\left(N_{\mathrm{e}}\right)$ were obtained from temporal changes in allelic frequencies between annual samples using two different approaches: (a) the standardised variance of allele frequency change, as detailed in Waples $(1989,1990)$ for model II (sampling without replacement of adult fish before reproduction), and (b) the pseudo-likelihood method of Wang and Whitlock (2003) implemented in the program MLNe v1.0, that estimates migration (the proportion of genes flowing into a population per generation) and $N_{\mathrm{e}}$ simultaneously (Wang 2001). We corrected for age-specific differences in reproductive value (e.g. Lande and Barrowclough 1987), although not for the effect of overlapping generations, by weighing the generation time for each population $(T)$, according to the following expression that takes into account the size of spawners as a proxy for their relative contribution to reproduction (Wang pers. comm.):

$$
T_{\mathrm{adj}}=\frac{\sum P_{i} R_{i} i}{\sum P_{i} R_{i}}
$$

where $P_{i}$ is the proportion of individuals of each age class $(i)$ and $R_{i}$ is the relative contribution of each age class to the next generation, estimated as the ratio between its average body weight and the average body weight of the heaviest age class (excluding mature male parr). Adjusted generation times $\left(T_{\mathrm{adj}}\right)$ were 2.84 years in the Asón, 3.04 years in the Pas, and 2.65 years in both the Nansa and the Deva (Table 1). As the intervals between samplings were not integers (because of overlapping generations), we approximated the estimates of $N_{\mathrm{e}}$ and $m$ obtained with the Wang and Whitlock method using the diffusion approximation by rounding the sampling interval $(t)$ to the nearest integer and using it in the estimation. The estimates of $N_{\mathrm{e}}$ and $m$ were then obtained from the following expressions (Wang and Whitlock 2003):

$$
\widehat{N}_{\mathrm{e}}=(T / t) N_{\mathrm{e}}^{\prime} \text { and } \widehat{m}=1-\mathrm{e}^{(t / T) \log \left(1-m^{\prime}\right)}
$$

For historical comparisons, $N_{\mathrm{e}}$ could only be estimated as for an isolated population (without considering migration), as sufficient historical samples were only available for the R. Asón from 1960 onwards (samples from the 1950 decade were limited). For modern samples, we estimated $N_{\mathrm{e}}$ with and without migration to check for congruence of results obtained under different model assumptions (Waples 1990; Wang and Whitlock 2003).

Estimates of gene flow $\left(N_{e} m\right)$ and migration rates (m) between populations

Gene flow $\left(N_{\mathrm{e}} m\right)$ between Iberian populations was estimated from $\theta$ values (Weir and Cockerman 1984) using GENETIX 4.01 and pooling data from five returning years (1996-2000). Although not all the assumptions of the model are fulfilled by the study populations and the resulting estimates do not probably measure gene flow accurately (Whitlock and McCauley 1999; Wilson et al. 2004), they do provide an indication of the relative isolation of populations. Estimates of migration rates per generation $(m)$ were obtained by the temporal method implemented in MLNe v1.0 (Wang and Whitlock 2003), which does not assume a closed population, and considers migration in addition to genetic drift in the estimation of $N_{\mathrm{e}}$ (Østergaard et al. 2003; Wang and Whitlock 2003). For each river we considered the three remaining populations as a source of migrants, pooling their allelic frequencies to represent a single source population. Comparison between estimates of migration and gene flow were used to approximate the level of exchange between populations. The Bayesian approach implemented in GENECLASS 1.0 (Cornuet et al. 1999) was used to assign fish to their river of origin.

\section{Mark-recapture studies}

In addition to molecular methods, the exchange of migrants between populations was estimated from 208 river recaptures of returning adults, that had been coded-wire tagged (CWT) as juveniles and stocked in three of the Iberian rivers as part of a captive breeding programme using native fish that started in 1996 (Garcia de Leániz et al. 2001). All angled fish plus a sample of spawners from every river were screened for tags every year. During the 1999-2000 spawning season, a sample of spawners caught at a fish trap near the uppermost accessible point of the R. Nansa was batch-marked with a 
panjet inoculator and transported downstream close to the river mouth on several occasions. An estimate of the size of the breeding population, along with $95 \%$ confidence intervals, was obtained by the recapture of marked fish using the modified Schnabel method described in Krebs (1989).

\section{Results}

\section{Hardy-Weinberg equilibrium}

The estimated frequency of null alleles in the two microsatellites that consistently deviated from $\mathrm{H}-\mathrm{W}$ equilibrium were $P(0)=0.020$ for SSsp2213, and $P(0)=0.381$ for SSsp2215. As a result, SSsp2215 was excluded from most of the analyses (comparisons with Scottish populations, $N_{\mathrm{e}}$ estimates). The rivers Asón and Pas did not show any significant deviation from $\mathrm{H}-\mathrm{W}$ equilibrium in any of the remaining microsatellites, but there was a deficiency of heterozygotes in the cohorts of 1997 (SSsp2201, $P<0.01$ and SSsp2216, $P<0.01$ ) and 1996 (SSsp 1605, $P<0.01$ ) in the River Nansa, and also in the cohorts of 1993 (SSsp1605, $P<0.01$ and SSsp2216, $P<0.001)$ and 1996 (SSsp2201, $P<0.01$ ) in the river Deva. All historical samples deviated from Hardy-Weinberg equilibrium, possibly as a consequence of pooling the samples by decades to increase the sample size.

Amplification success in the historical samples from the River Asón decreased with increasing allele size, and also with the age of the samples. Thus, only five microsatellites could be used in the historical comparisons, as only a small number of old scales could be typed for SSsp2216. Replicated genotyping was performed throughout, but we cannot completely disregard the possibility of allele drop out in some of the oldest samples.

\section{Temporal stability in allelic frequencies between cohorts and decades}

Allelic frequencies were not stable over time, mainly due to differences between cohorts at the SSsp2215 locus (probably due to the relatively high frequency of null alleles and the lower reliability of the corrected allelic frequencies). Significant differences in SSsp2215 were found between the 1998 cohort and the other year classes, both in the River Asón $(P<0.001)$ and in the River Pas
$(P<0.001)$. In the River Nansa, significant differences between cohorts were observed for SSsp2210 $(P<0.001)$ and SSsp2215 $(P<0.001)$, while in the River Deva all loci showed significant differences in allelic frequencies between cohorts.

Allelic frequencies also showed significant temporal heterogeneity between historical and modern samples from the River Asón. Most differences were due to heterogeneity between the 1950-1960 decades compared to the 1980s and 1990s samples, except for Ssa2213 which remained stable over time. The 1950 and 1960 decades did not differ significantly in any of the microsatellites, but significant differences were found between the following paired comparisons (after performing Bonferroni correction): 1950-80: 2 loci, 1950-90: 3 loci, 1960-80: 3 loci, 1960-90: 3 loci, 1980-90: 1 locus.

\section{Allelic richness, heterozygosity and evidence of bottlenecks}

Unlike allelic frequencies, allelic richness was stable between years classes in all four Iberian populations $(P>0.05)$, despite wide variations in year class strength (Table 2). The Deva population had the lowest average allelic richness (5.126 alleles per locus) while the Pas had the highest (5.184 alleles per locus), but differences were not significant between rivers $(P>0.05)$. Although the lowest allelic richness tended to coincide with the smallest cohorts, no significant association was detected between allelic richness and year class strength for any of the populations (Spearman rank correlation, $P>0.05$ in all cases).

Heterozygosity was high and stable in all rivers (Table 2), and - like allelic richness - did not differ between Iberian populations $(P>0.05)$. The lowest heterozygosities tended to be found in the least abundant year classes, but a positive association between heterozygosity and year class strength was only significant for the R. Asón $(\mathrm{Rs}=+0.899$, $P<0.05$ ). Evidence of bottlenecks, on the other hand, was found in all rivers, typically on those year classes of low strength (Figure 4).

Comparisons with the three large Scottish populations (Figure 5) showed that the four Iberian populations had the lowest allelic richness, although the differences were not significant. Iberian and Scottish populations displayed similar levels of heterozygosity, and these appear largely unrelated to population size or to region of origin. 
Table 2. Microsatellite variation in adult Atlantic salmon returning to four Iberian populations grouped by year class

\begin{tabular}{|c|c|c|c|c|c|c|}
\hline River & Year class & Year class strength $(S)$ & $N$ & $R a(10)$ & $\mathrm{He}$ & SE \\
\hline \multicolumn{7}{|c|}{ Present populations } \\
\hline \multirow[t]{7}{*}{ Asón } & 1993 & 68 & 22.83 & 5.351 & 0.802 & 0.088 \\
\hline & 1994 & 38 & 17.83 & 5.467 & 0.809 & 0.066 \\
\hline & 1995 & 23 & 22.00 & 5.470 & 0.802 & 0.085 \\
\hline & 1996 & 19 & 20.17 & 5.332 & 0.785 & 0.128 \\
\hline & 1997 & 9 & 5.17 & 4.768 & 0.721 & 0.088 \\
\hline & 1998 & 11 & 9.33 & 4.944 & 0.749 & 0.123 \\
\hline & Total & & 108 & 5.222 & & \\
\hline \multirow[t]{7}{*}{ Pas } & 1993 & 92 & 23.00 & 5.228 & 0.789 & 0.084 \\
\hline & 1994 & 21 & 14.33 & 5.233 & 0.779 & 0.086 \\
\hline & 1995 & 17 & 18.17 & 4.793 & 0.761 & 0.124 \\
\hline & 1996 & 22 & 22.00 & 5.215 & 0.789 & 0.097 \\
\hline & 1997 & 95 & 60.67 & 5.206 & 0.800 & 0.099 \\
\hline & 1998 & 81 & 14.33 & 5.428 & 0.773 & 0.153 \\
\hline & Total & & 169 & 5.184 & & \\
\hline \multirow[t]{7}{*}{ Nansa } & 1993 & 66 & 19.17 & 5.357 & 0.797 & 0.090 \\
\hline & 1994 & 36 & 16.17 & 4.897 & 0.705 & 0.159 \\
\hline & 1995 & 25 & 24.67 & 5.694 & 0.827 & 0.068 \\
\hline & 1996 & 21 & 55.17 & 5.998 & 0.847 & 0.079 \\
\hline & 1997 & 38 & 50.33 & 5.359 & 0.810 & 0.081 \\
\hline & 1998 & 54 & 16.67 & 5.406 & 0.790 & 0.082 \\
\hline & Total & & 205 & 5.452 & & \\
\hline \multirow[t]{6}{*}{ Deva } & 1993 & 223 & 43.67 & 5.351 & 0.785 & 0.121 \\
\hline & 1994 & 28 & 14.33 & 5.467 & 0.744 & 0.126 \\
\hline & 1995 & 5 & 5.67 & 5.470 & 0.743 & 0.064 \\
\hline & 1996 & 14 & 11.67 & 5.332 & 0.798 & 0.076 \\
\hline & 1997 & 95 & 37.67 & 4.768 & 0.762 & 0.17 \\
\hline & Total & & 125 & 5.126 & & \\
\hline \multicolumn{7}{|c|}{ Historical populations } \\
\hline & Decade & Harmonic mean catch & $\mathrm{n}$ & $R a(10)$ & $\mathrm{He}$ & SE \\
\hline \multirow[t]{4}{*}{ Asón } & $1950 \mathrm{~s}$ & 703.2 & $14.2(23)$ & 5.478 & 0.801 & 0.069 \\
\hline & $1960 \mathrm{~s}$ & 736.9 & $16.6(31)$ & 5.101 & 0.776 & 0.071 \\
\hline & $1980 \mathrm{~s}$ & 23.4 & $28.2(41)$ & 5.649 & 0.820 & 0.057 \\
\hline & $1990 \mathrm{~s}$ & 51.6 & $108.2(121)$ & 5.450 & 0.815 & 0.099 \\
\hline
\end{tabular}

Year class strength $(S)$ is the total (aggregate) number of angled adults originating from each cohort during the period 1996-2002, $N$ is the average sample size per locus, $\operatorname{Ra}(10)$ is the allelic richness (averaged over all loci) adjusted to a minimum sample size of 10 alleles, $H e$ is the average heterozygosity, and SE is the standard error. In the analysis of present populations six loci were screened and only individuals that could be assigned to their year class were considered; in the historical analysis, five loci were screened and all sampled fish (shown in brackets) were included.

Thus, while the river North Esk had a significantly higher heterozygosity than the four Iberian populations $(P<0.001)$ - and the Oykel population was higher than the Deva $(P=0.001)$ - the rivers Asón and Nansa had a higher heterozygosity than the Shin $(P<0.001)$. Thus consistent differences in heterozygosity appear not to be found between Iberian and Scottish populations, despite large differences in population size.

Likewise, the analysis of historical samples from the river Asón (Table 2) revealed no signifi- cant changes in either allelic richness $(P>0.05)$ or heterozygosity $(P>0.05)$ during the last five decades, despite a dramatic reduction in population size, as inferred from the pattern of declining rod catches (Figure 2).

\section{Effective population size}

The effective population size per generation of Iberian populations, estimated by the maximum likelihood method $\left(\mathrm{MLN} N_{\mathrm{e}}\right)$ and considering 

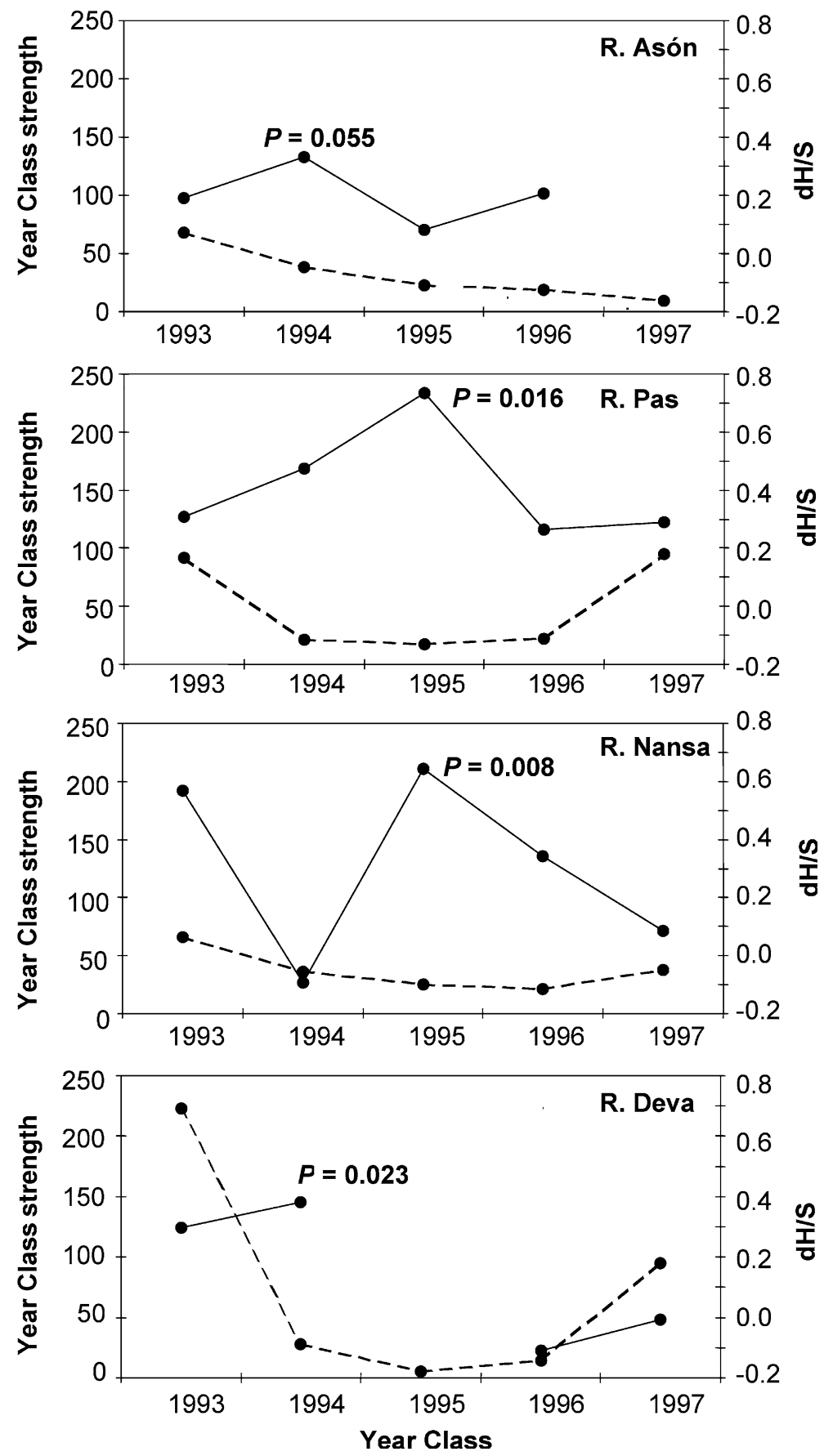

Figure 4. Evidence of genetic bottlenecks in Iberian populations (dH/S-continuous lines) measured as the standardized excess of heterozygosity (Hobs-Hexp/standard deviation) with respect to the number of alleles (Cornuet and Luikart 1997) and estimates of year class strength (discontinuous line), expressed as the aggregated number of adults from each cohort angled during the period $1996-2002$. Probabilities refer to cohorts with evidence of bottlenecks; only complete cohorts with sufficient number of fish were tested.

migration, was always below 50 individuals (Table 3), ranging from a minimum of 12 for the R. Asón to a maximum of 31 for the river Nansa.
Estimates of $N_{\mathrm{e}}$ without considering migration were larger and very similar between methods, ranging from 42 (R. Asón) to 175 (R. Pas) based 

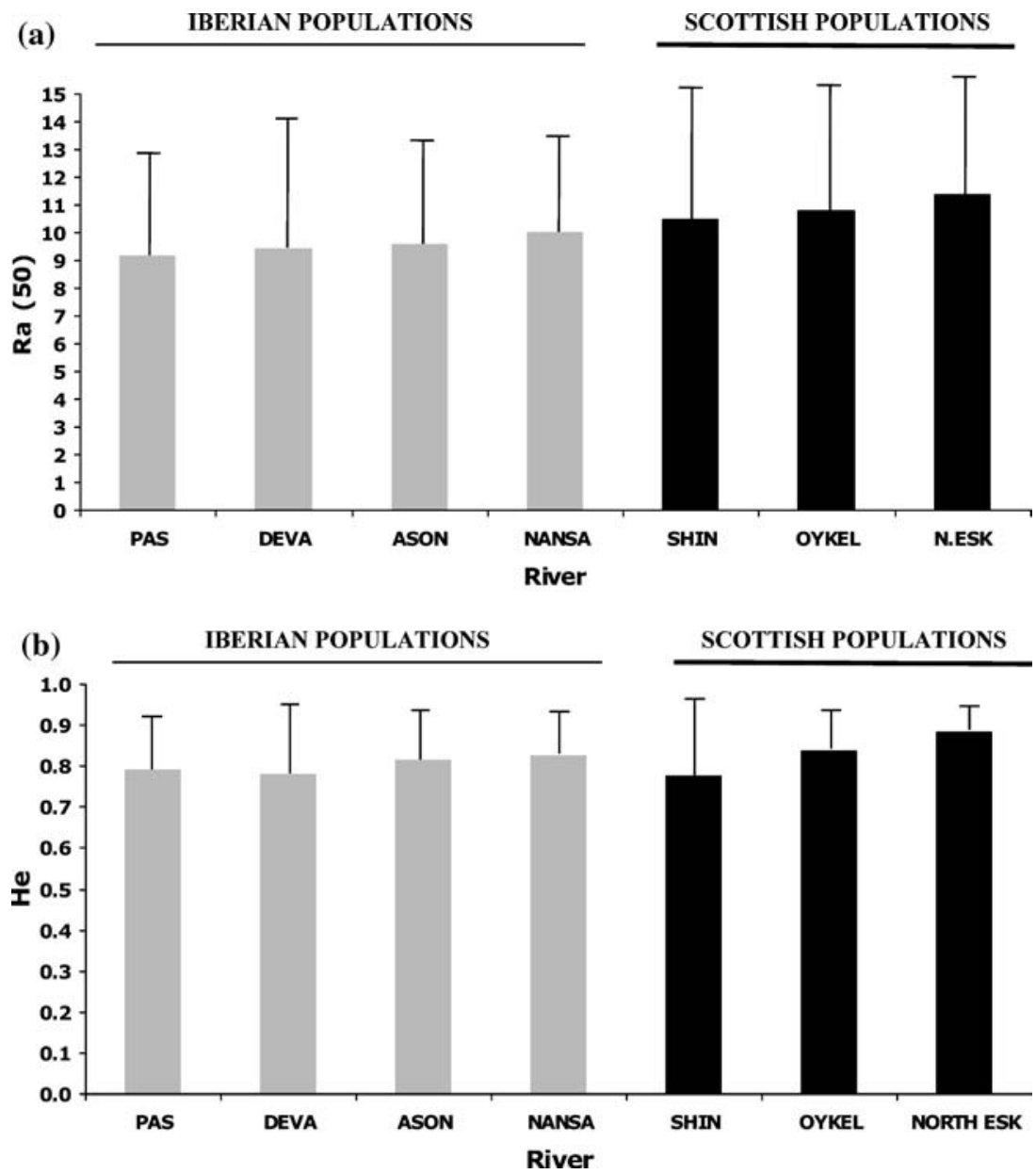

Figure 5. Estimates of (a) allelic richness approximated to a minimum sample size of 50 genes (Ra50; SD indicated) and (b) heterozygosity (He; SE indicated) in four small populations from the Iberian peninsula (Asón, Pas, Nansa and Deva) and three larger population from Scotland (Shin, Oykel, North Esk).

on the variance in the allelic frequencies (Waples 1990) and from 38 (R. Asón) to 98 (R. Pas) estimated with the maximum likelihood method (Wang 2001). The demographic estimates $\left(N_{\mathrm{eH}}\right)$ were larger, but always below 500 effective breeders per generation in all populations, again being lowest in the R. Asón $\left(N_{\mathrm{eH}}=121\right)$ and largest in the R. Nansa $\left(N_{\mathrm{eH}}=499\right)$. The contribution of mature parr to reproduction was taken into account by considering an average of 8 mature male parr per spawning female, which is consistent with field studies in Iberian populations (Martinez et al. 2002) and also with $N_{\mathrm{e}}$ simulations (Figure 3). The estimated effect of the contribution of mature male parr was to increase $N_{\mathrm{e}}$ by 1.5-2.2 times in Iberian populations (Table 4), although these are probably maximum values because individual differences in reproductive success were not considered (Garant et al. 2001).

The estimated ratio between effective population size and census size in extant populations ranged from 0.04 to 0.18 (Table 3) for genetic estimates without considering migration $($ mean $=0.10)$ and from 0.02 to $0.04($ mean $=0.03)$ when migration was taking into account. Corresponding demographic $N_{\mathrm{e}} / N$ ratios were larger $($ mean $=0.27)$, probably due to differences in reproductive success within sexes, not considered in the demographic estimates. Genetic estimates of $N_{\mathrm{e}} / N$ ratios based only on adult censuses (without mature male parr), varied between 0.08 and 0.14 considering migration and from 0.18 to 0.54 without migration. These values are similar to those obtained in other salmonids (Bartley et al. 
Table 3. Demographic and genetic estimates of census size $\left(N_{\mathrm{T}}\right)$ and effective population size per generation (95\% CI in parentheses), based on Wright (1938) expression for unequal sex ratio of spawners ( $N_{\mathrm{eH}}$, harmonic mean), and the temporal method as implemented by Waples (1990) and by Wang and Whitlock (2003)

\begin{tabular}{|c|c|c|c|c|c|c|c|c|c|c|c|}
\hline \multirow[t]{2}{*}{ River } & \multirow[t]{2}{*}{ Period } & \multirow[t]{2}{*}{$G$} & \multicolumn{3}{|c|}{$\begin{array}{l}\text { Demographic } \\
\text { estimates }\end{array}$} & \multicolumn{2}{|c|}{$\begin{array}{l}\text { Closed populations } \\
\text { without immigration }\end{array}$} & \multicolumn{2}{|c|}{$\begin{array}{l}\text { Closed populations } \\
\text { without immigration }\end{array}$} & \multicolumn{2}{|c|}{$\begin{array}{l}\text { Open populations } \\
\text { with immigration }\end{array}$} \\
\hline & & & $N_{\mathrm{T}}$ & $N_{\mathrm{eHT}}$ & $N_{\mathrm{eHT}} / N$ & $N_{\text {e (1) }}$ & $N_{\mathrm{e}(1)} / N_{\mathrm{T}}$ & $N_{\mathrm{e}(2)}$ & $N_{\mathrm{e}(2)} / N_{\mathrm{T}}$ & $N_{\mathrm{e}(3)}$ & $N_{\mathrm{e}(3)} / N_{\mathrm{T}}$ \\
\hline \multicolumn{12}{|c|}{ Historical analysis } \\
\hline Asón & 1960-1986 & 9.15 & 9686 & 445 & 0.04 & $109(60-168)$ & 0.01 & $90(59-149)$ & 0.009 & - & - \\
\hline Asón & 1986-1996 & 3.52 & 2375 & 386 & 0.16 & $95(46-157)$ & 0.04 & $55(34-109)$ & 0.02 & - & - \\
\hline \multicolumn{12}{|c|}{ Present day analysis } \\
\hline Asón & 1996-2000 & 1.41 & 477 & 121 & 0.25 & $42(21-67)$ & 0.09 & $38(27-87)$ & 0.08 & $12(11-16)$ & 0.02 \\
\hline Pas & 1996-2000 & 1.31 & 961 & 217 & 0.22 & $175(67-284)$ & 0.18 & $98(81-645)$ & 0.10 & $29(23-37)$ & 0.03 \\
\hline Nansa & 1996-2000 & 1.51 & 1541 & 499 & 0.32 & $68(33-110)$ & 0.04 & $74(38-313)$ & 0.05 & $31(24-42)$ & 0.02 \\
\hline Deva & 1996-2000 & 1.51 & 655 & 189 & 0.29 & $113(49-197)$ & 0.17 & $84(42-506)$ & 0.13 & $28(22-37)$ & 0.04 \\
\hline
\end{tabular}

For the historical analysis, the R. Asón has been considered only as an isolated population, while for the analysis of present populations migration has also been taken into account. $G$ : no. of elapsed generations, $N_{\mathrm{T}}$ : average no. of breeders, per generation, $N_{\text {eHT }}$ : harmonic mean of fluctuations in number of breeders (corrected by uneven sex ratio), per generation, $N_{\mathrm{e}(1)}$ : Waples (1990), per generation, $N_{\mathrm{e}(2)}$ : Wang and Whitlock (2003) without considering immigration, per generation, $N_{\mathrm{e}(3)}$ : Wang and Whitlock (2003) considering immigration from adjacent populations, per generation.

1992; Hedrick et al. 1995; Shrimpton and Heath 2003) and indicate that the effective population size is lower than half the census size. In the historical analysis of the river Asón population (Table 3), the genetic estimates of effective population size were under 110 individuals while the demographic estimates ranged from 386 to 445 for an estimated census size of 2375-9686 individuals per generation. In both cases (demographic and genetic estimates) the present day Asón population displays the lowest historical values of $N_{\mathrm{e}}$, thus mimicking the historical decline in rod catches (Figure 2).

\section{Asymmetric gene flow and migration between populations}

Estimates of gene flow $\left(N_{\mathrm{em}}\right)$ based on $\theta$ values (Table 5) suggest that the exchange of migrants between Iberian salmon populations is high, ranging from 16 to 46 individuals per generation. Migration rates $(m)$ estimated by the temporal method also appear to be high, and range between 0.58 and 0.72 . The river Asón appears to be the most isolated population of the four, and the only one that shows significant $\theta$ differences with respect to neighbouring Iberian populations.

Results from the recapture of 208 microtagged fish (Table 6) also reveal an asymmetric pattern of homing and straying between rivers. Homing rates ranged from $97 \%$ for the R. Nansa to $79 \%$ for the R. Pas, while strayers represented between $0 \%$ for R. Asón to over $27 \%$ for the R. Nansa, thus indicating an asymmetric, non-random pattern of dispersal $(G=241.4, \quad \mathrm{df}=4, \quad P=0.000)$. Most strayers originated from the River Pas and went into the River Nansa, while none went into the R. Asón. Hence it appears that while the Asón

Table 4. Demographic estimates of census size $\left(N_{\mathrm{T}}\right)$ and effective population size per generation $\left(N_{\mathrm{eHT}}\right.$, harmonic means) in the four Iberian populations during 1996-2000, considering that only anadromous males reproduce and the contribution of an average of 8 mature male parr per spawning female

\begin{tabular}{|c|c|c|c|c|c|c|c|c|c|}
\hline \multirow[t]{2}{*}{ River } & \multicolumn{4}{|c|}{ Anadromous males only } & \multicolumn{5}{|c|}{ Anadromous males +8 mature male parr } \\
\hline & Males & Females & $N_{\mathrm{T}}$ & $N_{\mathrm{eHT}}$ & Males & Females & $N_{\mathrm{T}^{\prime}}$ & $N_{\mathrm{eHT}^{\prime}}$ & $N_{\mathrm{eHT}^{\prime}} / N_{\mathrm{eHT}}$ \\
\hline Asón & 37 & 49 & 86 & 81 & 428 & 49 & 477 & 175 & 2.2 \\
\hline Pas & 107 & 95 & 202 & 189 & 866 & 95 & 961 & 342 & 1.8 \\
\hline Nansa & 249 & 144 & 393 & 343 & 1398 & 144 & 1542 & 521 & 1.5 \\
\hline Deva & 88 & 63 & 151 & 130 & 592 & 63 & 655 & 228 & 1.8 \\
\hline
\end{tabular}


Table 5. Estimates of gene flow $\left(N_{\mathrm{e}} m\right)$ between rivers based on $\theta$ (Weir and Cockerman 1984) and migration $(m)$ by the temporal method (Wang and Whitlock 2003) with $95 \%$ confidence intervals (95 C.I.)

\begin{tabular}{|c|c|c|c|c|c|c|}
\hline \multirow[t]{2}{*}{ River } & \multicolumn{3}{|c|}{ Gene flow } & \multirow[t]{2}{*}{ River } & \multicolumn{2}{|c|}{ Migration } \\
\hline & $\theta$ & 95 C.I. & $\mathrm{N}_{\mathrm{e}} m$ & & $m$ & 95 C.I. \\
\hline Asón-Deva & $0.016^{*}$ & $0.008-0.026$ & 15.6 & Asón & 0.58 & $0.25-0.75$ \\
\hline Asón-Nansa & $0.010^{*}$ & $0.006-0.013$ & 25.1 & Pas & 0.72 & $0.51-0.75$ \\
\hline Asón-Pas & $0.014 *$ & $0.008-0.021$ & 18.3 & Nansa & 0.58 & $0.27-0.73$ \\
\hline Deva-Nansa & 0.012 & $0.010-0.013$ & 21.4 & Deva & 0.74 & $0.58-0.85$ \\
\hline Deva-Pas & 0.005 & $0.001-0.010$ & 46.0 & & & \\
\hline Nansa-Pas & 0.006 & $0.004-0.007$ & 43.2 & & & \\
\hline
\end{tabular}

Only $\theta$ estimates for the R. Asón were significant $(* P<0.001)$.

population is relatively isolated, the populations of the Nansa and Pas may behave according to source-sink dynamics (i.e. Dias 1996).

In the neighbour-joining dendrogram based in $D_{\mathrm{A}}$ distances (Figure 6) the historical samples of the river Asón cluster very distant from the modern ones, with high genetic distance between them, compared with the shorter distances between the four modern samples. The river Asón, on the other hand, is the most distinct of the four modern Iberian populations (Asón-Pas:0.059; Asón-Deva:0.069) while the populations in the Pas and Deva appear to be the most similar (0.033).

\section{Discussion}

\section{Low effective population sizes and genetic bottlenecks}

The effective population size of the four Iberian salmon populations we analysed appears to be low, with $N_{\mathrm{e}}$ estimates ranging from 12 to 31 individuals (with migration) or from 38 to 175 individuals (without migration) using the temporal methods, and from 121 to 499 individuals using demographic data. These values are below the minimum of 500 estimated by Franklin (1980) to be necessary for avoiding the loss of genetic variability, and well under the 5000 suggested by Lande (1995).

Genetic estimates of effective population size considering migration were 2-3 times lower than those that assumed closed populations, as reported in other salmonids (e.g. Østergaard et al. 2003). Ignoring migration can greatly bias the estimation of effective population size, particularly when the sampling intervals are small and populations regularly exchange individuals (Wang and Whitlock 2003). Thus, the use of methods that incorporate migration should provide more realistic estimates of $N_{\mathrm{e}}$ in salmonids (Østergaard et al. 2003; Fraser et al. 2004), more congruent with results from physical tagging (Wilson et al. 2004). On the other hand, we found little difference between $N_{\mathrm{e}}$ temporal estimates for closed populations derived from changes in the variance of allele frequencies (Waples 1989, 1990) or the maximum likelihood method (Wang 2001). Both methods gave similar results for each river and singled out the River

Table 6. Distribution of adult recaptures and estimated rates (\%) of immigration and homing in three of the study populations (Asón, Pas and Nansa) based on the analysis of native salmon micro-tagged and stocked as juveniles during 1998-2002

\begin{tabular}{lcccrc}
\hline \multirow{2}{*}{ River of origin } & \multicolumn{2}{l}{ River of recapture } & & Homing $(\%)$ \\
\cline { 2 - 5 } & Asón & Pas & Nansa & Total \\
\hline Asón & 22 & 1 & 2 & 25 & 88.0 \\
Pas & 0 & 88 & 24 & 78.6 \\
Nansa & 0 & 2 & 69 & 97.2 \\
Total & 22 & 91 & 95 & 208 & 12 \\
Immigration (\%) & 0.00 & 3.30 & 27.4 & 14.0 \\
\hline
\end{tabular}




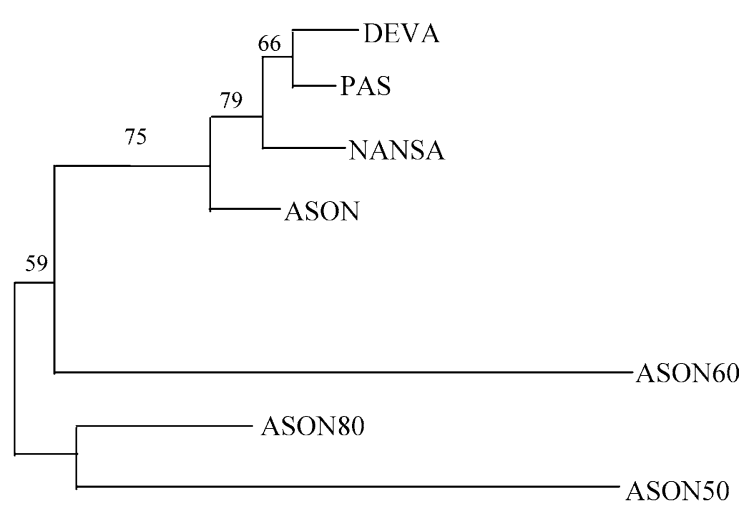

0.1

Figure 6. Neighbour-joining dendrogram based on Nei's $D_{\mathrm{A}}$ distance (Nei et al. 1983) showing relationship between historical samples from the river Asón (ASON50, ASON60, ASON80) and modern samples (1996-2000) from the four Iberian populations studied. Numbers above each node denote bootstrapping values greater than $50 \%$ after 1000 replicates.

Asón as the population with the lowest effective population size.

Our demographic estimates of $N_{\mathrm{e}}$ were based on fluctuations in census size without considering differences in reproductive success, and assumed that census size (number of spawners) could be estimated from redd counts and information on sex ratios; therefore, they must necessarily be considered as rough approximations, and probably overestimate the real $N_{\mathrm{e}}$. Moreover, the assumption of one female per redd may have overestimated the number of spawners if multiple redd construction was more frequent than redd overlapping. However, demographic and ML estimates of $N_{\mathrm{e}}$ ranked the size of the four Iberian populations in the same order, the R. Asón always being the smallest, and the R. Nansa always being the largest. These results are consistent with what is known about the relative size, stability, and conservation status of these populations (Figure 2; Garcia de Leániz et al. 2001). Also, in the R. Nansa we found a reasonably good correspondence among three independent estimates of the size of the annual breeding population (anadromous): 106 spawners based on redd counts and sex ratio, 152 spawners based on visual counts, and 132 spawners $(95 \% \mathrm{CI}=71-320)$ based on mark and recapture estimates. These census estimates are similar to the census range of $88-382$ anadromous spawners reported by Dumas and Prouzet (2003) for the nearby R. Nivelle. Fur- thermore, the estimated $N_{\mathrm{e}} / N$ ratios for Iberian populations (0.02-0.54 using genetic data and 0.22-0.32 using demographic information) are close to theoretical predictions (Waples, 2004), and very similar to values found in other anadromous populations (L'Abée-Lund 1989; Hedrick et al. 1995; Waples 2002a,b; Shrimpton and Heath 2003). Thus, it seems that our estimates of census size and effective population sizes are probably sound, and confirm the precariously low abundance of these Iberian salmon populations, as had previously been inferred from the declining trend in angling catches (Figure 2).

In the case of the River Asón, the historical decrease in the genetic estimates of $N_{\mathrm{e}}$ seems to track well the observed demographic decline in census size, although the historical $N_{\mathrm{e}} / N$ ratio appears to have been lower, perhaps due to the limitations of estimating census size from historical catches alone. Some evidence of genetic bottlenecks was found in all four Iberian populations, but only in those cohorts of low year class strength - in all cases below 40 adults ( $\sim 16-32$ spawning females), suggesting that bottlenecks may only be readily detected at very low population sizes, as indicated by Luikart et al. (1999).

\section{Genetic diversity}

Despite their reduced size and evidence of genetic bottlenecks, the four Iberian salmon populations seem to maintain relatively high levels of genetic diversity, comparable to those found in three larger, more stable Scottish populations. In general, we found little or no relationship between estimates of effective population size (or census size) and measures of genetic diversity. Only in the smallest, most isolated population (R. Asón) was there a positive relationship between abundance (as inferred from estimates of year class-strength) and heterozygosity in modern samples. Furthermore, the temporal analysis with archival scales from the R. Asón failed to detect any historical loss of allelic richness or heterozygosity, which is somewhat surprising considering the apparent intensity and duration of the population crash in this river (Table 2 and Figure 2). The only detectable long-term genetic effect in the R. Asón was a change in allelic frequencies, which we attribute to drift, and which is also evident in mitochondrial DNA haplotype frequencies 
(Consuegra et al. 2002). The fact that the historical samples from the R. Asón cluster together with the present samples indicates that, despite the reduction in size and change in allele frequencies, the population still maintains a certain degree of genetic identity.

Such apparent lack of correspondence between population size and genetic diversity is not new. It is a puzzling, widespread paradigm observed in species as different as the Mauritius kestrel (Nichols et al. 2001), the African buffalo (Wenink et al. 1998), the Indian rhinoceros (Dinerstein and McCracken 1990), or the grizzly bear (Miller and Waits 2003). It is also a common phenomenon in salmonids (Heath et al. 2002; Laikre et al. 2002; Østergaard et al. 2003), where genetic variation may only be weakly related to population size or to fitness (Wang et al. 2002), possibly due to genetic compensation (e.g. Ardren and Kapuscinski 2003). Thus while Palm et al. (2003) found a positive relation between effective population size and genetic diversity in brown trout, Jorde and Ryman (1996) reported the same level of heterozygosity across a wide range of $N_{\mathrm{e}}$ values. Similarly, Säisa et al. (2003) found high heterozygosity in an Atlantic salmon population (Iijoki stock) with a $N_{\mathrm{e}}$ below 80 for several generations, remaining apparently unchanged even when $N_{\mathrm{e}}$ was as low as 13 fish.

Several reasons can be suggested for the maintenance of relatively high levels of genetic diversity in Iberian salmon populations, comparable to those found in populations from Scotland. First, Iberian populations predate the last glacial maximum (Consuegra et al. 2002) and may be expected to harbour more genetic diversity than populations from colonised areas further north (Hewitt 1999), at least with respect to allelic richness (Comps et al. 2001). If so, present levels of genetic diversity in Iberian populations may reflect the eroding effect of bottlenecks acting on formerly higher levels of genetic variation. However, no such erosion was detected within the time frame of the present study, despite evidence of bottlenecks. Second, the complex life cycle of Atlantic salmon with overlapping generations and multiple paternity may help to minimise or delay the loss of genetic diversity in the face of demographic catastrophes (Waples 1991), especially if bottlenecks are only short, point events (Primack 1998). However, inspection of historical catch statistics suggests that demographic catastrophes, at least in the R. Asón, seem to have been long and intense. Third, the contribution of mature male parr to reproduction may help to increase $N_{\mathrm{e}}$ and genetic diversity (L'Abée-Lund 1989; Jones and Hutchings 2001; Taggart et al. 2001), especially in southern rivers, where development is fast and maturation rates are high (Martinez et al. 2000). Our demographic estimates suggest that mature parr could increase the effective population size of these populations by up to 2.2 times, although these are maximum values as they do not take into account differences in spawning success (Taggart et al. 2001; Kalinowski and Waples 2002). The actual contribution of mature male parr is probably more limited and unlikely to maintain genetic diversity on its own, and $N_{\mathrm{e}}$ appears to be below 100 individuals even considering the presence of mature male parr. Indeed, the contribution of more than eight male parr per spawning female may make little difference in augmenting $N_{\mathrm{e}}$ in these populations if the sex ratio of spawners is currently biased towards males due to the increasing incidence of late grilse and the steady decline of spring females (Consuegra et al. 2005). Finally, the maintenance of genetic diversity in these small, peripheral populations may have been facilitated by asymmetric dispersal and gene flow, especially during periods of low abundance, as our results strongly suggest (Figure 7).

\section{Dispersal and asymmetric gene flow}

Dispersal may allow individuals to survive in unstable environments (Unwin and Quinn 1993; Lenormand 2002) and to cope with local demographic bottlenecks (Fraser et al. 2004), if migrants attain higher fitness and reduce the likelihood of inbreeding depression (reviewed by Hendry et al. 2004). Thus dispersal may be favoured in small, peripheral salmonid populations living in marginal habitats if it helps to increase $N_{\mathrm{e}}$ and maintain genetic variation (Jorde and Ryman 1996; Laikre et al. 1998, 2002; Palm et al. 2003).

Our combined estimates of dispersal, derived from physical tagging and microsatellite data (Tables 5 and 6), suggest that there is a substantial exchange of migrants between Iberian salmon populations, though the extent to which they overestimate gene flow is difficult to quantify accurately (e.g. Wilson et al. 2004). Dispersal 


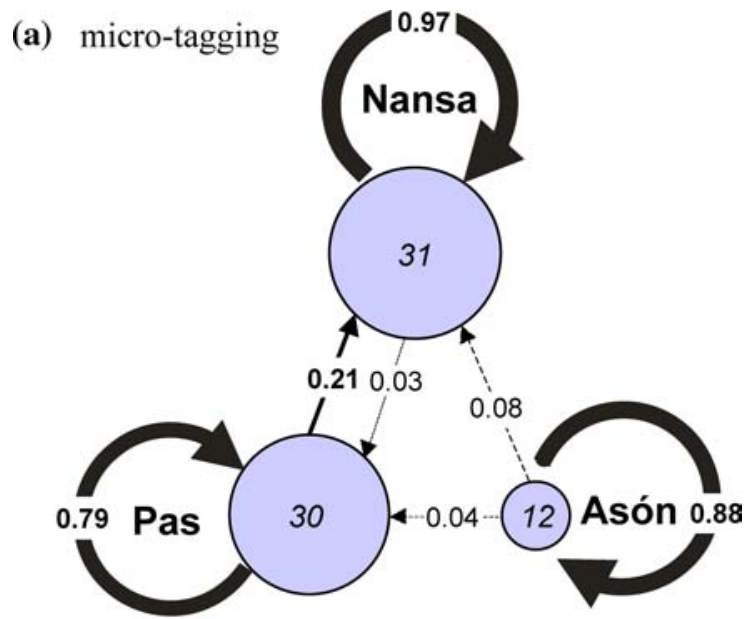

(b)

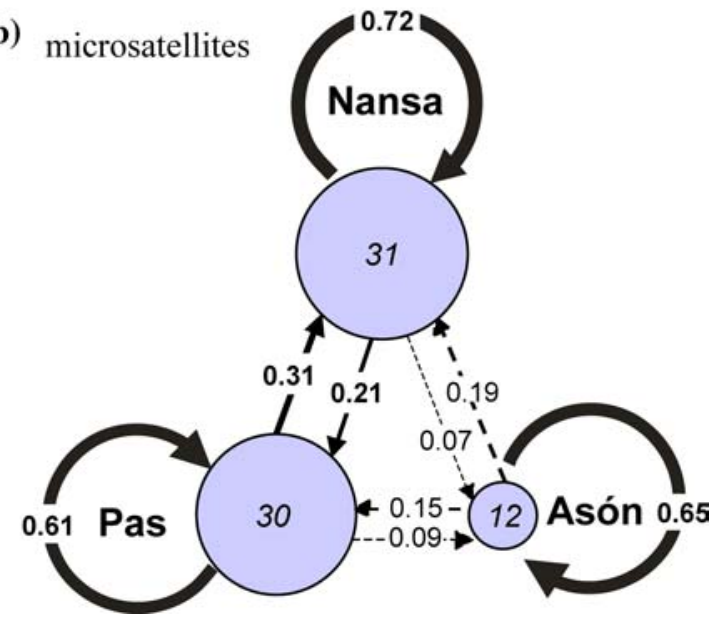

Figure 7. Inferred patterns of dispersal and asymmetric gene flow between the rivers Asón, Pas, and Nansa based on (a) recaptures of micro-tagged adults stocked as juveniles in each river, and (b) microsatellite variation and Bayesian assignment tests (Cornuet et al. 1999). Size of circles is proportional to $N_{\mathrm{e}}$ estimated by the temporal method (Wang and Whitlock 2003), while size of arrows is proportional to the inferred proportion of fish migrating between rivers. Continuous lines denote strong directional flows $(>0.20)$ while dotted lines denote weaker relationships $(<0.20)$.

estimates derived from physical tagging of stocked fish tend to overestimate gene flow because not all strayers reproduce successfully (Tallman and Healey 1993; Fleming et al. 2000; Hendry 2001), and because hatchery-reared juveniles tend to stray more than native fish (Quinn 1993; Schroeder et al. 2001; Jonsson et al. 2003). Thus, although the time spent in the hatchery was relatively short in our study (8-10 months) - and we stocked the juveniles in their parent river, our estimates of straying (2.8-21.4\%) may have been overestimated. Comparative straying rates in English salmon populations similar to ours were $3 \%$ for hatchery fish and $2 \%$ for wild fish (Potter and Russell 1994), so it is possible that we overestimated dispersal. Nevertheless, that would still imply a substantial scope for gene flow between Iberian populations.

On the other hand, estimates based on $\theta$ values would also tend to overestimate gene flow (Whitlock and McCauley 1999), particularly among populations with low differentiation (Wilson et al. 2004) screened with a limited number of microsatellites, as was the case in our study ( $\max$ $\theta=0.016)$. Nevertheless, the high migration rates estimated between Iberian populations $(m=0.58$ 0.72 ), although similar to those obtained with the same maximum-likelihood method for brown trout living in unstable streams $(m=0.23-0.99$; Østergaard et al. 2003) and for coho salmon (Ford et al. 2004), are likely to be overestimates. Indeed, the fact that allelic frequencies were significantly different between Iberian populations for the six microsatellites $(P<0.005)$ indicates that enough differentiation continues to exist in spite of gene flow.

Migration estimates obtained with the Wang and Whitlock (2003) maximum likelihood method appear to be unrealistically high for Atlantic salmon, and this could be the reason for the significantly larger $N_{\mathrm{e}}$ estimates when migration is not considered. The observed discrepancy in $N_{\mathrm{e}}$ estimates with and without migration has also been noted in coho salmon (Ford et al. 2004). Although there are probably several reasons for such discrepancy, it seems that at least two of the underlying model assumptions, namely non-overlapping generations and constant migration rates between years, are unrealistic in the case of Atlantic salmon.

Our results may have also been affected by stocking in the study rivers, but this possibility seems small considering the poor return rates of previous stocking programmes (Garcia de Leániz et al. 1989; Verspoor and Garcia de Leániz 1997) and the calendar of the ongoing stocking programme (Garcia de Leániz et al. 2001). We only considered wild adults in our analysis (identified by the presence of adipose fins), and the stocking programme that begun in 1996 (with $\sim 73,000$ native juveniles and an estimated recapture rate of 
$0.1 \%$ ) only started to yield adult returns in 1998 . Thus, the potential contribution of offspring from stocked fish to our samples would have been limited to a small proportion of fish in the 2000 run, our last sampling year. However, the possible effect of stocking may need to be accounted for in the future, because the release of large numbers of hatchery fish (even of native parents) could increase gene flow (Storfer 1999) and result in further genetic homogenisation (Lenormand 2002).

Regardless of the real magnitude of gene flow, both the micro-tagging and microsatellite data indicate that the exchange of migrants between Iberian populations is not symmetrical (Figure 7), but appears instead to conform to a "source-sink" metapopulation scenario (e.g. Dias 1996; Hanski 1999; Rieman and Dunham 2000). Thus, the R. Asón that has the smallest and most unstable population size, is also the population that exchanges the fewest number of migrants, being separated to the nearest populations by $50 \mathrm{~km}$ to the west and by $140 \mathrm{~km}$ to the east. The genetic distance to other populations, the similarity between historical and present samples, and the absence of recaptures from the other rivers all support the relative isolation of the R. Asón, perhaps reflecting an Allee effect (reduced per capita growth rate at low population sizes) accompanied by increasing isolation at low densities (cf. Hanski, 1999). Alternatively, the low connectivity and small population size of the R. Asón may simply reflect an impoverished habitat. In contrast, the R. Nansa seems to maintain the largest, most stable population (according to demographic and genetic estimates assuming migration), it is flanked by two neighbouring populations, and it seems to be acting as a "sink" receiving the largest number of strayers from other rivers, particularly from the R. Pas which behaves as a "source" (Table 6 and Figure 7). The number of migrants that one river receives seems to increase with water discharge (Unwin and Quinn 1993) and also with annual returns (Quinn and Fresh 1984; Jonsson et al. 2003). These could explain in part the high proportion of immigrants found in the Nansa (Table $6-27 \%$ ), whose discharge is regulated by a hydro-electric dam and tends to maintain the largest flow during the dry season. The Nansa has also the largest, most stable population (Table 3 and Figure 2) and a better habitat (Garcia de Leániz et al. 2001), which may have helped to attract strayers from other populations by increasing their fitness (the conspecific attraction hypothesis - Hanski 1999) or by buffering them against temporal variation in habitat quality (Hendry et al. 2004).

In brief, our results indicate that the effective population size of the four Iberian salmon populations we analysed is very small, well under the size suggested necessary to maintain genetic diversity and long-term population viability. Yet, the four Iberian populations seem to maintain relatively high levels of genetic diversity, similar to those found in much larger Scottish populations. Furthermore, in the case of the R. Asón we could not detect any historical loss of genetic diversity despite a dramatic decline in abundance. Although several mechanisms may have helped to minimise or delay the loss of genetic variation, our results suggest that asymmetric gene flow resulting from source-sink metapopulation dynamics (Hanski, 1999; Fraser et al. 2004) has probably been the dominant evolutionary strategy for maintaining genetic diversity in Iberian salmon populations living in marginal, peripheral habitats.

\section{Acknowledgements}

We thank Angel Serdio, Leticia González and the Cantabrian wildlife bailiffs for help with the collection of samples, and Martha O'Sullivan and Teresa Amigo for help with microsatellite genotyping. Jinliang Wang provided invaluable assistance with the estimation of effective population size and his help is gratefully acknowledged. We also thank Bill Jordan, Robin Waples and two anonymous referees for useful comments that greatly improved the manuscript.

\section{References}

Adkison MD (1995) Population differentiation in Pacific salmon: Local adaptation, genetic drift, or the environment? Can. J. Fish. Aquat. Sci., 52, 2762-2777.

Allendorf FW, Bayles D, Bottom DL, Currens KP, Frissell CA, Hankin D, Lichatowich JA, Nehlsen W, Trotter PC, Williams TH (1997) Prioritizing Pacific salmon stocks for conservation. Conserv. Biol., 11, 140-152.

Ardren WR, Kapuscinski AR (2003) Demographic and genetic estimates of effective population size $\left(N_{\mathrm{e}}\right)$ reveals genetic compensation in steelhead trout. Mol. Ecol., 12, 35-49. 
Avise JC (1994) Molecular Markers, Natural History and Evolution, Chapman \& Hall, New York.

Bartley D, Bagley M, Gall G, Bentley B (1992) Use of linkage disequilibrium data to estimate effective size of hatchery and natural fish populations. Conserv. Biol., 6, 365-375.

Beacham TD, Dempson JB (1998) Population structure of Atlantic salmon from the Conne River, Newfoundland as determined from microsatellite DNA. J. Fish Biol., 52, 665-676.

Bernatchez L, Wilson CC (1998) Comparative phylogeography of Nearctic and Palearctic fishes. Mol. Ecol., 7, 431-452.

Brookes MI, Graneau YA, King P, Rose OC, Thomas CD, Mallet JLB (1997) Genetic analysis of founder bottlenecks in the rare British butterfly Plebejus argus. Conserv. Biol., 11, 648-661.

Brookfield JFY (1996) A simple new method for estimating null allele frequency from heterozygote deficiency. Mol. Ecol., 5, 453-455.

Comps B, Gömöry D, Letouzey J, Thiébaut B, Petit RJ (2001) Diverging trends between heterozygosity and allelic richness during postglacial colonization in the European Beech. Genetics, 157, 389-397.

Consuegra S, García de Leániz C, Serdio A, González Morales M, Straus LG, Knox D, Verspoor E (2002) Mitochondrial DNA variation in Pleistocene and modern Atlantic salmon from the Iberian glacial refugium. Mol. Ecol., 11, 2037-2048.

Consuegra S, García de Leániz C, Serdio A, Verspoor E (2005) Selective exploitation of early running fish may induce genetic and phenotypic changes in Atlantic salmon. J. Fish Biol., 67 (Suppl. A) 129-145.

Cornuet JM, Piry S, Luikart G, Estoup A, Solignac M (1999) New methods employing multilocus genotypes to select or exclude populations as origins of individuals. Genetics, 153, 1989-2000.

Daniels SJ, Triddy JA, Walters JR (2000) Inbreeding in small populations of red-cockaded woodpeckers: Insights from a spatially explicit individual-based model. In: Genetics, Demography and Viability of Fragmented Populations (eds. Young AG, Clarke GM), pp. 129-148. Cambridge University Press, Cambridge.

Dempster AP, Laird NM, Rubin DB (1977) Maximum likelihood from incomplete data via the EM algorithm. J. Roy. Stat. Soc. B, 39, 1-38.

Dias PC (1996) Sources and sinks in population biology TREE, 11, 326-330.

Dinerstein E, McCraken GF (1990) Endangered greater onehorned rhinoceros carry high levels of genetic variation. Conserv. Biol., 4, 417-422.

Dodson JJ, Gibson RJ, Cunjak RA, Friedland KD, García de Leániz C, Gross MR, Newbury R, Nielsen JL, Power ME, Roy S (1998) Elements in the development of conservation plans for Atlantic salmon (Salmo salar). Can. J. Fish. Aquat. Sci., 55, 312-323.

Dumas J, Prouzet P (2003) Variability of demographic parameters and population dynamics of Atlantic salmon Salmo salar L. in a south-west French river. ICES Journal of Marine Science, 60, 356-370.

Fleming IA, Hindar K, Mjølnerød IB, Jonsson B, Balstad T, Lamberg A (2000) Lifetime success and interactions of farm salmon invading a native population. Proc. Roy. Soc. Lond. (B), 267, 1517-1523.
Ford MJ, Teel D, Van Doornik DM, Kuligowski D, Lawson PW (2004) Genetic population structure of central Oregon Coast coho salmon (Onchorynchus kisutch). Conserv. Genet., 5, 797-812.

Frankham R (1996) Relationship of genetic variation to population size in wildlife Conserv. Biol., 10, 1500-1508.

Frankham R, Ballou JD, Briscoe DA (2002) Introduction to Conservation Genetics, Cambridge University Press, Cambridge.

Franklin IR (1980) Evolutionary change in small populations In: Conservation Biology: An Evolutionary-Ecological Perspective (eds. Soulé ME, Wilcox BA), pp. 135-149. Sinauer Associates, Sunderland, MA.

Fraser DJ, Lippé C, Bernatchez L (2004) Consequences of unequal population size, asymmetric gene flow and sexbiased dispersal on population structure in brook charr (Salvelinus fontinalis). Mol. Ecol., 13, 67-80.

Garant D, Dodson JJ, Bernatchez L (2001) A genetic evaluation of mating system and determinants of individual reproductive success in Atlantic salmon (Salmo salar L.). J. Hered., 92, 137-145.

García de Leániz C, Martínez JJ (1988) The Atlantic salmon in the rivers of Spain with particular reference to Cantabria. In: Atlantic Salmon: Planning for the Future (eds. Mills D, Piggins D), pp. 179-209. Croom Helm, London.

García de Leániz C, Verspoor E, Hawkins AD (1989) Genetic determination of the contribution of stocked and wild Atlantic salmon, Salmo salar L., to the angling fisheries in two Spanish rivers. J. Fish Biol., 35, 261-270.

García de Leániz C, Caballero P, Valero E, Martínez JJ, Hawkins AD (1992) Historical changes in some Spanish rod and line salmon, Salmo salar L. fisheries: Why are large multi-seawinter fish becoming scarcer?. J. Fish Biol., 41, 179.

García de Leániz C, Serdio A, Consuegra S (2001) Situación actual del salmón atlántico en Cantabria (Present status of Atlantic salmon in Cantabria [In Spanish]). In: El Salmón, Joya de Nuestros Ríos (eds. García de Leániz C, Serdio A, Consuegra S), pp. 55-82. Consejería de Ganadería, Agricultura y Pesca, Santander.

Hanski I (1999) Metapopulation Ecology, Oxford University Press, New York.

Hauser L, Adcock GJ, Smith PJ, Ramirez JHB, Carvalho GR (2002) Loss of microsatellite diversity and low effective population size in an overexploited population of New Zealand snapper (Pagrus auratus). Proc. Natl. Acad. Sci. USA, 99, 11742-11747.

Heath DD, Busch C, Kelly J, Atagi DY (2002) Temporal change in genetic structure and effective population size in steelhead trout (Oncorhynchus mykiss). Mol. Ecol., 11, 197-214.

Hedrick PW, Hedgecock D, Hamelberg S (1995) Effective population size in winter-run chinook salmon. Conserv. Biol., 9, 615-624.

Hedrick PW (2000) Genetics of Populations, 2nd edn. Jones and Bartlett Publishers, Sudbury, MA.

Hendry AP (2001) Adaptive divergence and the evolution of reproductive isolation in the wild: An empirical demonstration using introduced sockeye salmon. Genetica, 112-113, 515-534.

Hendry AP, Castric V, Kinnison MT, Quinn TP (2004) The evolution of philopatry and dispersal. In: Evolution 
Illuminated. Salmon and their Relatives (eds. Hendry AP, Stearns SC), pp. 52-91. Oxford University Press, New York.

Hewitt GM (1999) Post-glacial re-colonization of European biota. Biol. J. Linn. Soc., 68, 87-112.

Jones MW, Hutchings JA (2001) The influence of male parr body size and mate competition on fertilization success and effective population size in Atlantic salmon. Heredity, 86, 675-684.

Jonsson B, Jonsson N, Hansen LP (2003) Atlantic salmon straying from the River Imsa. J. Fish Biol., 62, 641-657.

Jorde PE, Ryman N (1996) Demographic genetics of brown trout (Salmo trutta) and estimation of effective population size from temporal change of allele frequencies. Genetics, 143, 1369-1381.

Kalinowski ST, Waples RS (2002) Relationship of effective to census size in fluctuating populations. Conserv. Biol., 16, 129-136.

Keller LF, Arcese P, Smith JNM, Hochachka WM, Stearns SC (1994) Selection against inbred song sparrows during a natural population bottleneck. Nature, 372, 356-357.

Keller LF, Waller DM (2002) Inbreeding effects in wild populations. TREE, 17, 230-241.

Krebs CJ (1989) Ecological Methodology, Harper Collins Publishers, New York.

L'Abée-Lund JH (1989) Significance of mature male parr in a small population of Atlantic salmon (Salmo salar). Can. J. Fish. Aquat. Sci., 46, 928-931.

Laikre L, Jorde PE, Ryman N (1998) Temporal change of mitochondrial DNA haplotype frequencies and female effective size in a brown trout (Salmo trutta) population. Evolution, 52, 910-915.

Laikre L, Järvi T, Johansson L, Palm S, Rubin JF, Glimsäter CE, Landergren S, Ryman N (2002) Spatial and temporal population structure of sea trout at the Island of Gotland, Sweden, delineated from mitochondrial DNA. J. Fish Biol., 60, 49-71.

Lande R, Barrowclough GF (1987) Effective population size, genetic variation, and their use in population management. In: Viable Populations for Conservation (eds. Soulé ME), pp. 87-123. Cambridge University Press, New York.

Lande R (1995) Mutation and conservation Conserv. Biol., 9, 782-791.

Lenormand $T$ (2002) Gene flow and the limits to natural selection TREE, 17, 183-189.

Luikart G, Cornuet JM, Allendorf FW (1999) Temporal changes in allele frequencies provide estimates of population bottleneck size. Conserv. Biol., 13, 523-530.

Martinez JL, Moran P, Perez J, de Gaudemar B, Beall E, Garcia-Vazquez E (2000) Multiple paternity increases effective size of southern Atlantic salmon populations. Mol. Ecol., 9, 293-298.

Miller CR, Waits LP (2003) The history of effective population size and genetic diversity in the Yellowstone grizzly (Ursus arctos): Implications for conservation. Proc. Natl. Acad. Sci. USA, 100, 4334-4339.

Mills LS, Allendorf FW (1996) The one-migrant-per-generation rule in conservation and management. Conserv. Biol., 10, $1509-1518$.

Moran P (2002) Current conservation genetics: Building an ecological approach to the synthesis of molecular and quantitative genetic methods. Ecol. Freshw. Fish, 11, 3055.

Mousadik AE, Petit RJ (1996) High level of genetic differentiation for allelic richness among populations of the argan tree (Argania spinosa (L.) Skeels) endemic of Morocco. Theor. Appl. Genet., 92, 832-839.

Nei M, Tajima F, Tateno Y (1983) Accuracy of estimated phylogenetic trees from molecular data II. Gene frequency data. J. Mol. Evol., 153-170.

Nichols RA, Bruford MW, Groombridge JJ (2001) Sustaining genetic variation in a small population: Evidence from the Mauritius kestrel. Mol. Ecol., 10, 593-602.

Nunney L (1993) The influence of mating system and overlapping generations on effective population size. Evolution, 47, 1329-1341.

Ota T (1993) DISPAN: Genetic Distance and Phylogenetic Analysis, Institute of Molecular Evolutionary Genetics, The Pennsylvania State University, Pennsylvania, USA.

Østergaard S, Hansen MM, Loeschcke V, Nielsen EE (2003) Long-term temporal changes of genetic composition in brown trout (Salmo trutta L.) populations inhabiting an unstable environment. Mol. Ecol., 12, 3123-3135.

Palm S, Laikre L, Jorde PE, Ryman N (2003) Effective population size and temporal genetic change in stream resident brown trout (Salmo trutta, L.). Conserv. Genet., 4, 249-264.

Parrish DL, Behnke RJ, Gephard S, McCormick SD, Reeves GH (1998) Why aren't there more Atlantic salmon (Salmo salar)? Can. J. Fish. Aquat. Sci., 55, 281-287.

Paterson S, Piertney SB, Knox D, Gilbey J, Verspoor E (2004) Characterisation and PCR multiplexing of novel highly variable tetranucleotide Atlantic salmon (Salmo salar L.) microsatellites. Mol. Ecol. Notes, 4, 160-162.

Petit RJ, Mousadik AE, Pons O (1998) Identifying populations for conservation on the basis of genetic markers. Conserv. Biol., 12, 844-855.

Piry S, Luikart G, Cornuet JM (1999) BOTTLENECK: A computer program for detecting recent reductions in the effective population size using allele frequency data. J. Hered., 90, 502-503.

Potter ECE, Russell IC (1994) Comparison of the distribution and homing of hatchery-reared and wild Atlantic salmon, Salmo salar L., from north-east England. Aquat. Fish. Mgmt., 25, 31-44.

Primack RB (1998) Essentials of Conservation Biology, 2nd edn. Sinauer Associates Publishers, Sunderland, MA.

Quinn TP, Fresh K (1984) Homing and straying in chinook salmon (Oncorhynchus tshawytscha) from Cowlitz River hatchery, Washington. Can. J. Fish. Aquat. Sci., 41, 1078-1082.

Quinn TP (1993) A review of homing and straying of wild and hatchery-produced salmon. Fish. Res., 18, 29-44.

Raymond M, Rousset F (1995) GENEPOP (vers. 1.2): Population Genetics Software for Exact Tests and Ecumenicism. J. Hered., 86, 248-249.

Rice WR (1989) Analyzing tables of statistical tests. Evolution, 43, 223-225.

Rieman BE, Dunham JB (2000) Metapopulations and salmonids: A synthesis of life history patterns and empirical observations. Ecol. Freshw. Fish, 9, 51-64.

Säisä M, Koljonen M-L, Tähtinen J (2003) Genetic changes in Atlantic salmon stocks since historical times and the effective 
population size of a long-term captive breeding programme. Conserv. Genet., 4, 613-627.

Saccheri I, Kuussaari M, Kankare M, Vikman P, Fortelius W, Hanski I (1998) Inbreeding and extinction in a butterfly metapopulation. Nature, 392, 491-494.

Schroeder RK, Lindsay RB, Kenston KR (2001) Origin and straying of hatchery winter steelhead in Oregon coastal rivers. Trans. Am. Fish. Soc., 130, 431-441.

Shearer WM (1992) The Atlantic Salmon: Natural History, Exploitation and Future Management, Fishing News Books, London.

Sherwin WB, Moritz C (2000) Managing and monitoring genetic erosion. In: Genetics, Demography and Viability of Fragmented Populations (eds. Young AG, Clarke GM), pp. 9-34. Cambridge University Press, Cambridge.

Shrimpton JM, Heath DD (2003) Census vs. effective population size in chinook salmon: Large- and small-scale environmental perturbation effects. Mol. Ecol., 12, 2571-2583.

Sokal RR, Rohlf FJ (1995) Biometry, 3rd edn. W.H. Freeman and Co, New York.

Spidle AP, Kalinowski ST, Lubinski BA, Perkins DL, Beland KF, Kocik JF, King TL (2003) Population structure of Atlantic salmon in Maine with reference to populations from Atlantic Canada. Trans. Am. Fish. Soc., 132, 196-209.

Storfer A (1999) Gene flow and endangered species translocations: A topic revisited. Biol. Conserv., 87, 173-180.

Taggart JB, Hynes RA, Prodöhl PA, Ferguson A (1992) A simplified protocol for routine total DNA isolation from salmonid fishes. J. Fish Biol., 40, 963-965.

Taggart JB, McLaren IS, Hay DW, Webb JH, Youngson AF (2001) Spawning success in Atlantic salmon (Salmo salar L.): A long-term DNA profiling-based study conducted in a natural stream. Mol. Ecol., 10, 1047-1060.

Tallman RF, Healey MC (1993) Homing, straying and gene flow among seasonally separated populations of Chum salmon (Oncorhynchus keta). Can. J. Fish. Aquat. Sci., 51, 577-588.

Taylor EB (1991) A review of local adaptations in Salmonidae, with particular reference to Pacific and Atlantic salmon. Aquaculture, 98, 185-207.

Unwin MJ, Quinn TP (1993) Homing and straying patterns of chinook salmon (Oncorhynchus tshawytscha) from a New Zealand hatchery: Spatial distribution of strays and effects of release date. Can. J. Fish. Aquat. Sci., 50, 1168-1175.

Verspoor E (1988) Reduced genetic variability in first-generation hatchery populations of Atlantic salmon (Salmo salar). Can. J. Fish. Aquat. Sci., 45, 1686-1690.

Vrijenhoek RC (1994) Genetic diversity and fitness in small populations In: Conservation Genetics (eds. Loeschcke V, Tomiuk J, Jain SK), pp. 37-53. Birkhäuser Verlag, Basel.

Vucetich JA, Waite TA, Nunney L (1997) Fluctuating population size and the ratio of effective to census population size. Evolution, 51, 2017-2021.
Vucetich JA, Waite TA (1998) On the interpretation and application of mean times to extinction. Biodiv. Conserv., 7, $1539-1547$.

Vucetich JA, Waite TA (1999) Erosion of heterozygosity in fluctuating populations. Conserv. Biol., 13, 860-868.

Wang J (2001) A pseudo-likelihood method for estimating effective population size from temporally spaced samples. Genet. Res., 78, 243-257.

Wang J, Whitlock MC (2003) Estimating effective population size and migration rates from genetic samples over space and time. Genetics, 163, 429-446.

Wang S, Hard JJ, Utter F (2002) Genetic variation and fitness in salmonids. Conserv. Genet., 3, 321-333.

Wang J (2004) Application of the one-migrant-per-generation rule to conservation and management. Conserv. Biol., 18, 332-343.

Waples R (1989) A generalized approach for estimating effective population size from temporal changes in allele frequency. Genetics, 121, 379-391.

Waples R (1990) Conservation genetics of Pacific salmon: III, estimating effective population size. J. Hered., 81, 277-289.

Waples RS (1991) Pacific salmon, Oncorhynchs spp, and the definition of "species" under the Endangered Species. Acta Mar. Fish. Rev., 53, 11-21.

Waples RS (1998) Evolutionary significant units, distinct population segments, and the Endangered Species Act: Reply to Pennock and Dimmick. Conserv. Biol., 12, 718-721.

Waples RS (2002a) Effective size of fluctuating salmon populations. Genetics, 161, 783-791.

Waples RS (2002b) Evaluating the effect of stage-specific survivorship on the $N_{\mathrm{e}} / N$ ratio. Mol. Ecol., 11, 1029-1037.

Waples RS (2004) Salmonid insights into effective population size In: Evolution Illuminated Salmon and their Relatives (eds. Hendry AP, Stearns SC), pp. 295-314. Oxford University Press, New York.

Weir BS, Cockerman CC (1984) Estimating $F$-statistics for the analysis of population structure. Evolution, 38, 1358-1370.

Wenink PW, Groen AF, Roelke-Parker ME, Prins HHT (1998) African buffalo maintain high genetic diversity in the major histocompatibility complex in spite of historically known population bottlenecks. Mol. Ecol., 7, 1315-1322.

Whitlock MC, McCauley DE (1999) Indirect measures of gene flow and migration: $F_{\mathrm{ST}} \neq 1 /(4 N m+1)$. Heredity, 82, 117125.

Wilson AJ, Hutchings JA, Ferguson MM (2004) Dispersal in a stream dwelling salmonid: Inferences from tagging and microsatellite studies. Conserv. Genet., 5, 25-37.

Wright S (1938) Size of population and breeding structure in relation to evolution. Science, 87, 430-431.

WWF (2001): The Status of Wild Atlantic Salmon: A River by River Assessment. WWF. 